\title{
LATIHAN SQUAT DENGAN PROGRESSIVE RESISTANCE EXERCISE (PRE) UNTUK PENDERITA OSTEOARTHRITIS (OA)
}

\section{SQUAT EXERCISE WITH PROGRESSIVE EXERCISE (PRE) FOR OSTEOARTHRITIS (OA)}

\author{
Warih Anjari Dyah K. \\ warihd@ymail.com \\ Program Studi DIV Fisioterapi, STIKES Nasional, Surakarta
}

RESISTANCE

\section{Abstrak}

Penderita Osteoarthritis mempunyai keluhan nyeri sendi yang khas yaitu nyeri yang bertambah berat pada waktu menopang berat badan atau saat aktifitas, rasa kaku pada waktu pagi serta rasa pegal bila sendi lama diistirahatkan. Pada pemeriksaan fisik ditemukan nyeri tekan, krepitasi dengan atau tanpa keterbatasan gerak sendi. Penderita Osteoarthritis ekstremitas bawah dapat mengalami keterbatasan dalam aktifitas sehari-hari seperti berjalan, mandi, berpakaian, menggunakan toilet, dan mengerjakan pekerjaan rumah tangga. Kelemahan otot quadriceps merupakan keadaan yang sering dijumpai pada pasien Osteoarthritis lutut yang kemudian akan menjurus pada disused atropi hal ini diakibatkan oleh kurangnya penggunaan otot tersebut pada sisi lutut yang sakit.

Tujuan penelitian ini untuk mengetahui pengaruh kedua latihan terhadap penderita Osteoarthritis. Metodologi yang digunakan dalam penelitian ini yaitu Pre and Post Test with Control Group Design.

Hasil menunjukkan nilai signifikansi baik pada kelompok squat exercise dan progressive resistance exercise terhadap peningkatan aktifitas fungsional pada Osteoarthritis lutut semua bernilai $p<0,05$ menunjukkan bahwa Close kinetic chain $(p=0,00)$ dan Progressive Resistance Exercise $(p=0,001)$ sama-sama berpengaruh terhadap peningkatan aktifitas fungsional pada Osteoarthritis lutut. Ada perbedaan pengaruh latihan Squat dengan progressive resistance exercise dalam meningkatkan aktifitas fungsional pada penderita Osteoarthritis lutut

Kata Kunci : latihan squat, progressive resistance exercise, Osteoarthritis

\section{Abstract}

Osteoarthritis sufferers have a typical joint pain that is pain that increases weight when sustaining body weight or during activity, stiffness in the morning and feeling sore when the old joints are rested. On physical examination found tenderness, crepitations with or without restricted joint motion. Patients with lower extremity osteoarthritis may experience limitations in daily activities such as walking, bathing, dressing, using toilets, and doing household chores. Quadriceps muscle weakness is a common condition in patients with knee osteoarthritis which leads to disused atrophy due to the lack of use of the muscle on the sick side of the knee.

The purpose of this study to determine the effect of both exercises on Osteoarthritis patients. The methodology used in this research is Pre and Post Test with Control Group Design.

The results showed that the value of significance in both the squat exercise and progressive resistance exercise groups on the increase of functional activity in knee OA were all $p<0.05$ indicating that Close kinetic chain $(p=0.00)$ and Progressive Resistance Exercise ( $p=0.001$ ) similarly affects the increased functional activity in knee osteoarthritis. There is a difference in the effect of Squat exercise with progressive resistance exercise in improving functional activity in patients with knee osteoarthritis

Keywords : squat exercise, progressive resistance exercise, Osteoarthritis 


\section{Pendahuluan}

Osteoarthritis merupakan penyakit sendi yang paling banyak ditemukan di dunia termasuk di Indonesia. Penyakit ini menyebabkan nyeri dan gangguan gerakan sendi sehingga mengganggu aktifitas sehari-hari. Kelainan utama pada Osteoarthritis adalah kerusakan rawan sendi yang sering diikuti penebalan tulang subkondral, pertumbuhan osteofit, kerusakan ligamen serta kapsul sendi, dan sering dijumpai tanda peradangan pada sinovial, sehingga dalam sendi tidak jarang dijumpai efusi.

Dalam hal ini perlu penanganan pada gangguan fungsi lutut baik secara medis maupun secara fisioterapi. Dalam penelitian ini, peneliti menggunakan terapi latihan Latihan Squat Dengan Progressive Resistance Exercise dalam meningkatkan Aktifitas Fungsional pada penderita Osteoarthritis sendi lutut, dimana Latihan Squat mengacu pada gerakan yang terjadi dalam rantai kinematik tertutup di mana tubuh bergerak, misalnya gerakan rantai tertutup terjadi dalam posisi menurunkan tubuh seperti pada naik tangga atau saat jongkok. Sedangkan Progressive Resistance Exercise adalah latihan penguatan isotonik dinamik dengan beban ditingkatkan bertahap. Latihan penguatan dengan Progressive Resistance exercise lebih baik untuk menjaga dan meningkatkan fungsi otot, mengurangi nyeri sendi, dan meningkatkan fungsi pasien Osteoarthritis lutut.

Tujuan dari penelitian ini adalah (1) Untuk mengetahui pengaruh latihan Squat terhadap peningkatan aktifitas fungsional pada Osteoarthritis lutut. (2) Untuk mengetahui pengaruh latihan Progressive Resistance Exercise terhadap peningkatan aktifitas fungsional pada Osteoarthritis lutut. (3) Untuk mengetahui perbedaan pengaruh latihan Squat dengan Progressive Resistance Exercise dalam meningkatkan aktifitas fungsional pada Osteoarthritis lutut.

\section{Metode Penelitian}

\section{Alat}

Alat yang digunakan dalam penelitian ini adalah Leg Dynamometer. Leg Dynamometer terdiri dari sabuk pengaman pinggang, sabuk pengait \& rantai penarik , tongkat penarik (khusus untuk penggunaan test kekuatan otot punggung), alas tumpuan dan unit pembaca hasil untuk mengetahui hasil pengukuran.

\section{Bahan} penelitian ini.

\section{Tahapan Penelitian}

Tahapan dalam penelitian ini adalah sebagai berikut :

a. Melakukan observasi tempat penelitian.

b. Menjelaskan kepada responden maksud dan tujuan penelitian.

c. Memberikan lembaran quisioner Womac dan menjelaskan tentang cara pengisiannya serta mengukur kekuatan ototnya dengan Leg Dynamometer.

d. Melaksanakan Latihan Squat dan Progressive Resistance Exercise 3 kali seminggu selama 4 minggu.

e. Setelah 4 minggu lembaran Womac dibagikan kembali dan dilakukan lagi pengukuran kekuatan otot dengan Leg Dynamometer.

f. Setelah data terkumpul kemudian dilakukan pengolahan data.

\section{Analisa Data}

Hasil uji normalitas data mendapatkan hasil uji dimana semua data berdistribusi normal dengan hasil selisih kedua penilaian Womac bernilai $p>0,05$. Pengujian beda pengaruh menggunakan uji Independent sampel t- test, dengan hasil sebagai berikut

Tabel I. Hasil uji Independent sampel t- test pada Selisih Close kinetic chain dan Static quadriceps

\begin{tabular}{lc}
\hline \multicolumn{1}{c}{ Data Uji } & Nilai \\
\hline Selisih Womac Close kinetic chain dan & 0,003 \\
Static quadriceps & \\
Selisih Leg Dynamometer & 0,005 \\
Womac Close kinetic Chain & 9.17 \\
Wo mac Static quadriceps & 3.83 \\
Leg Dynamometer Close kinetic chain & 3.00 \\
Leg Dynamometer Static quadriceps & 0.83 \\
\hline
\end{tabular}

Sumber : Hasil pengolahan data

Hasil interprestasi dari uji Independent sampel ttest menunjukkan bahwa nilai $p=0,003$ pada Selisih Close kinetic chain dan Static quadriceps hal ini menunjukkan bahwa terdapat beda pengaruh pada Close kinetic chain dan Static quadriceps terhadap peningkatan aktifitas fungsional pada OA dan pada peningkatan kekuatan otot lutut. Hasil hipotesa tersebut didukung dengan interprestasi nilai Mean, dengan hasil sebagai berikut :

Hasil pengolahan data didapatkan bahwa nilai Mean pada selisih Close kinetic chain memilikinilai 9,17 sedangkan selisih Static quadriceps adalah 3,83, dan pada peningkatan kekuatan otot dengan menggunakan Leg Dynamometer didapatkan hasil bahwa peningkatan kekuatan otot rata-rata dari Close kinetic chain adalah 3 sedangkan selisih Static quadriceps adalah 0,83, dari penilaian tersebut dapat 
disimpulkan bahwa pengaruh pemberian Close kinetic chain lebih besar pengaruhnya dibandingkan dengan Static quadriceps dalam meningkatkan aktifitas fungsional pada OA lutut di Panti Wreda Dharma Bhakti Surakarta.

\section{Hasil dan Pembahasan}

Hasil pada penilaian pengaruh Close kinetic chain dalam meningkatkan aktifitas fungsional $\mathrm{OA}$ lutut menunjukkan hasil nilai signifikansi $\mathrm{p}=.000(\mathrm{p}$ $<0,05)$ yang menunjukkan latihan Close kinetic chain berpengaruh dalam meningkatkan aktifitas fungsional pada $\mathrm{OA}$ lutut.

Hasil ini didukung oleh penelitian dari Marques dkk (2007) dalam penelitiannya tentang efek pemberian close kinetic chain pada subjek dengan patellofemoral syndrome mendapatkan hasil bahwa close kinetic chain efektif dalam peningkatan kemampuan fungsional, dan Hughes pada penelitiannya Conservative Management Of Cruciate Ligament Deficiency With Physical Therapy (2007) mendapatkan hasil bahwa close kinetic chain dapat digunakan untuk meningkatan kekuatan otot kaki dan aktifitas fungsional, sedangkan peningkatan kekuatan otot yang diukur menggunakan leg dynamometer pada latihan close kinetic chain pada penelitian ini mendapatkan hasil yang signifikan dimana nilai $p<0,05$. Hal ini sesuai dengan penelitian yang dilakukan oleh Bayrakci dkk (2009) dengan judul penelitian The effects of two different closed kinetic chain exercises on muscle strength and proprioception in patients with patellofemoral pain syndrome dimana dalam penelitian tersebut menunjukkan bahwa Closed Kinetic Chain memberikan efek peningkatan kekuatan otot, propioceptic dan aktivitas fungsional, karena pada prinsipnya latihan Closed Kinetic Chain melatih otot pada kontrol konsentrik dan eksentrik yang dilakukan secara sistematis memanfaatkan dari fenomena biomekanik dan fisiologi fungsional yang tidak tergantung terhadap gravitasi, ditambah dengan efek sistem tahanan pada neuromuscular-sistem untuk meningkatkan kondisi fisik aktif neuromuscular dan rehabilitasi dan hal inilah yang menyebabkan pengiriman sinyal ke otot menjadi semakin meningkat.

Pengaruh latihan static quadriceps exercise terhadap peningkatan aktifitas fungsional

Pada kelompok static quadriceps terhadap peningkatan aktifitas fungsional memperoleh hasil yang singnifikan yaitu $(p<0,05)$, yang menunjukkan bahwa latihan static quadriceps memberikan pengaruh terhadap peningkatan aktifitas fungsional.
Latihan static quadriceps memberikan pengaruh yang besar terhadap peningkatan kekuatan group otot-otot besar yang berfungsi sebagai flexor dan ekstensor lutut. Sehingga terjadi peningkatan kekuatan otot yang seimbang antara group otot-otot extensor lutut dan group otototot fleksor lutut. Hasil dari peneliti sebelumnya dengan menggunakan dua kelompok, kelompok kontrol tanpa diberi latihan isometric sedangkan pada kelompok perlakuan diberi tambahan latihan static quadriceps, dengan pengukuran menggunakan dynamometer. Hasil penelitian pada kelompok perlakuan menunjukkan adanya peningkatan kekuatan otot.

Beda pengaruh latihan close kinetic chain dengan static quadriceps terhadap peningkatan aktifitas fungsional

Hasil dari uji Independent sampel t-test menunjukkan bahwa nilai $\mathrm{p}=0,003$ pada selisih selisih Close kinetic chain dan Static quadriceps exercise, hal ini menunjukkan bahwa terdapat beda pengaruh pada Close kinetic chain dan Static quadriceps terhadap peningkatan aktifitas fungsional pada penderita OA dan pada peningkatan kekuatan otot lutut. Selain itu didapatkan pula nilai Mean pada selisih Close kinetic chain memiliki nilai 9,17 sedangkan selisih Static quadriceps adalah 3,83, dari penilaian tersebut menunjukkan bahwa pengaruh pemberian Close kinetic chain lebih besar pengaruhnya dibandingkan dengan Static quadriceps dalam meningkatkan aktifitas fungsional pada OA lutut di Panti Wreda Dharma Bhakti Surakarta.

Close chain exercise sangat bermanfaat untuk melatih otot-otot tungkai bawah terutama untuk meningkatkan kemampuan fungsional. Karena pada prinsipnya latihan Closed Kinetic Chain adalah latihan yang menguatkan otot agonis dan antagonis secara bersamaan dan merupakan latihan yang lebih fisiologi untuk anggota gerak bawah, dan peran dari masing-masing otot itu sendiri yaitu untuk otot quadriceps sebagai kontrak eksentrik untuk mengontrol fleksi lutut atau kontrak konsentris untuk memperpanjang lutut, paha belakang, dan soleus berfungsi untuk menstabilkan tibia. teknik gerak Closed Kinetic Chain adalah latihan gerak sesuai bidang anatomi sendi lutut yakni gerak fleksi-ekstensi dan gerak ditujukan untuk aktivitas sehari-hari (Activity daily living atau ADL) seperti jongkok ke berdiri dan Toileting. Dengan fleksibilitas dan kekuatan otot yang baik akan mendukung kemampuan gerak dalam melakukan aktivitas sehari-hari. kelentukan memegang peranan penting bagi segala tingkatan usia dalam menunjang 
aktivitas kehidupannya sehari-hari. Hal inilah yang menyebabkan terjadinya peningkatan aktivitas fungsional pada penderita OA, dengan meningkatnya kekuatan dan fleksibilitas otot, sehingga pencapaian nilai LGS dengan kekuatan otot yang bertambah membantu dalam gerak fungsi tubuh beraktivitas (Bayrakci, 2009).

\section{Simpulan}

Berdasarkan dari hasil analisa dan perhitungan uji statistik, dapat di ambil kesimpulan sebagai berikut:

1. Ada pengaruh latihan Close kinetic chain terhadap peningkatan aktifitas fungsional pada penderita Osteoarthritis (OA) lutut.

2. Ada pengaruh latihan Static quadriceps terhadap peningkatan aktifitas fungsional pada penderita Osteoarthritis $(\mathrm{OA})$ lutut.

3. Ada perbedaan pengaruh latihan Close kinetic chain dengan Static quadriceps dalam meningkatkan aktifitas fungsional pada penderita Osteoarthritis $(\mathrm{OA})$ lutut.

\section{Ucapan Terima Kasih}

Ucapan terimakasih saya berikan kepada narasumber dan mahasiswa yang ikut serta dalam pelaksanaan penelitian ini.

\section{Daftar Pustaka}

Bayrakci V, 2009; The Effects Of Two Different Closed Kinetic Chain Exercise On Muscle Strength And Proprioception In Patients With Patellofemoral Pain Syndrome. Acta orthop traumatol turc.

Hughes Laurie Edge-, Bscpt. 2007. Conservative Management Of Cruciate Ligament Deficiency With Physical Therapy. Cafci, Ccrt The Canine Fitness Centre Ltd, Calgary, Alberta, Canada

Marques, Amélia Pasqual, Cristina Maria Nunes Cabral1,2, Ângela Maria de Oliveira Melim2, Isabel deCamargo Neves Sacco. 2007. Effect Of A Closed Kinetic Chain Exercise Protocol Onpatello Femoral Syndrome Rehabilitation. XXV ISBSS Symposium 20 


\section{LAMPIRAN}

A. Tabel

\begin{tabular}{llr|lr}
\hline No & Data Close kinetic chain & Signifikansi & Data Static quadriceps & Signifikansi \\
\hline 1 & Womac Pre & .287 & Womac Pre & .179 \\
2 & Womac Post & .772 & Womac Post & .189 \\
3 & Womac Selisih & .181 & Womac Selisih & .535 \\
4 & Leg Dynamometer Pre & .242 & Leg Dynamometer Pre & .121 \\
5 & Leg Dynamometer Post & .293 & Leg Dynamometer Post & .070 \\
6 & Leg Dynamometer Selisih & .110 & Leg Dynamometer Selisih & .212 \\
\hline
\end{tabular}

Keterangan: *Dihitung terhadap berat ekstrak etanol 96\% $=20,1123 \mathrm{~g}$ 
